\title{
Drošības jautājumi: mūsdienu tendences Lietuvas tiesību aizsardzības sistēmā
}

\author{
Vladas Tumalavičius \\ G̦enerāḷa Jonasa Žemaiša Lietuvas Militārā akadēmija, Lietuva \\ vladas.tumalavicius@gmail.com
}

\section{Kopsavilkums}

Problēmas Lietuvas nacionālās drošības jomā liek pievērst uzmanību faktam, ka informācijas pārvaldība un izmantošana kā tradicionāla tiesībaizsardzības iestāžu darba metode ir mainīga paaugstinātas specdienestu iesaistǐšanās dēl, jo mūsdienās pastāv drošības draudi. Esošo un mērḳtiecīgi mainīgo Eiropas Savienības tiesību reformas jomas, drošības un nozīmīgu sociālo procesu nodrošināšanas integrācijas procesu novērošana un izpēte gūst ne tikai teorētisku, bet arī aizvien svarīgāku praktisku nozīmi, tāpēc ir pelnījusi ciešu zinātniskās sabiedrības, īpaši juridisko zinātṇu pārstāvju, uzmanību.

Darbā atspoguḷoti sabiedrības drošības tiesiskās regulěšanas attīstības pašreizējie jautājumi un jaunākās tendences, ko nosaka Lietuvas Republikas Kriminālās izlūkošanas likums, kas vēl nav pilnvērtīgi un detalizēti atspoguḷots zinātniskās diskusijās. Tāpēc radās nepieciešamība analizēt šì tiesību instrumenta iemiesojumu Lietuvas drošības dienestu slepenās darbības jomā mūsdienu globalizācijas procesā. Darbā tika izmantotas objektīvās realitātes izzināšanas un speciālā darba un paṇēmienu vispārzinātniskās metodes, kuras raksturīgas juridiskajām zinātnēm. Rezultātā ir uzsvērts šĩ tiesību instrumenta kā demokrātisko vērtību un cilvēka tiesību un brīvības aizsardzības garanta svarīgums un savlaicīgums.

Atslēgvārdi: cilvēka tiesības un brīvība, kriminālā izlūkošana, sabiedrības drošība.

\section{levads}

Kopš seniem laikiem operatīvās izmeklēšanas, izlūkošanas un pretizlūkošanas darbïbas pamats un kodols ir aǵentūras metode, t. i., slepenu darbinieku (aǵentu) un tiesībsargājošo orgānu operatīvo darbinieku un specdienestu paṇēmienu, veidu un 
uzvedības modeḷu kopums operatīvi nozīmīgas informācijas izdibināšanā un prettiesisku darbību dokumentēšanā, nodibinot vai attīstot uzticības pilnas attiecības ar šīs informācijas zinātāju.

Ievērojamā filozofa un domātāja Herodota (480. g. p. m. è.) darbos tiek norādìts, ka senie griek̦i izmantoja aǵentus no Persijas. Aǵentūru aktīvi izmantoja Maḳedonijas Aleksandrs un kartāgiešu generālis Hanibals. Daudz noderīga slepenā dienesta organizācijā un aǵentūras darba taktikā ieviesa mongoḷi. Čingishans aǵentūru novērtēja un aktīvi izmantoja, un, saprotot pretizlūkošanas pasākumu bīstamību, cietsirdīgi un nežēelīgi izrēḳinājās ar ienaidnieka spiegiem.

Kopš XVII gs. iezīmējās norobežošanās no aǵentūras metodes valsts iekšèjās drošības nodrošināšanā. Šim mērḳim sāka veidoties patstāvīgas struktūras, ko vēlāk nosauca par pretizlūkošanas dienestu. Piemēram, Krievijā imperatora gimenes un cariskā režīma drošîbas nodrošināšanai 1826. gadā tika organizēta politiskā policija kā Imperatora personīgās kancelejas trešā nodạla, kas aktīvi vervēja aǵentus un ziņotājus informācijas iegūšanai no personām, kuras tika turētas aizdomās par nelojalitāti pret carisko režìmu. Ieviesto vai iegūto aǵentūru ārvalstīs organizatoriski parasti īstenoja patstāvīgas struktūras, kas realizēja mērḳtiecīgu militāro vai iekšpolitisko izlūkošanu [9].

Kopš pirmajiem datiem par aǵentūru darba paṇēmieniem, kas minēti Vecajā Derībā, pagājuši gandrīz četri tūkstoši gadu, un vairāki simti tūkstošu cilvēku ik dienas tiek iesaistîti ag̣entūras darbā kā tiesībsargājošo un speciālo dienestu brīvprātīgie palīgi vai kā štata darbinieki, kuri nodrošina izlūkošanas, pretizlūkošanas un meklēšanas funkcijas. Kaut arī XXI gs. sākumā zinātniski tehniskā progresa ietekmē operatīvajā meklēšanas darbỉbā arvien aktīvāk tiek izmantotas informācijas tehnologijas, lai savāktu, analizētu un saglabātu konfidenciālu informāciju par personām un faktiem, kuri ir izraisījuši izlūkošanas, pretizlūkošanas un meklēšanas darbā iesaistīto interesi, daudzu gadsimtu garumā pārbaudītais darbs ar agentūru tomēr ir viens no efektīvākajiem līdzekḷiem cīṇā ar pārkāpumiem pret valsts interesēm, konstitucionālajām tiesībām un pilsoṇu brīvību [8].

\section{Kriminālās izlūkošanas koncepcija - jaunas vēsmas Lietuvas nacionālās drošỉbas nodrošināšanā}

Tiesībsargājošo iestāžu un citu specdienestu darbỉbu cīṇā ar noziedzību Lietuvā līdztekus atklāta rakstura darbībām nosaka arī slēpta, nevienam neredzama darbība, ko reglamentē dažādu resoru dokumentu statūti, slepenas instrukcijas, prokuratūras rekomendācijas, kā arī tiesiskie akti, no kuriem vissvarīgākais ir jaunais likums, kas nosaka kriminālās izlūkošanas veikšanu un ar to saistītās darbības. 
Lietuvas Republikas Kriminālās izlūkošanas likums stājās spēkā 2013. gada 1. janvārī [1]. Vienlaikus ar šĩ likuma stāšanos spēkā spēku ir zaudējis līdz šim pastāvošais Lietuvas Republikas Operatīvās darbības likums, kas nepietiekami sekmēja cilvēka tiesību un brīiības aizsardzības nodrošināšanu, operatīvās darbības subjektu kontroli, tikai daḷēji noteica to uzvedības pamatus, kā arī neatbilda pastāvošajai situācijai. Pieṇemtais Lietuvas Republikas Kriminālās izlūkošanas likums reglamentē kriminālās izlūkošanas pamatus, tās subjektu tiesības un pienākumus, izmeklēšanas veikšanu, finansēšanu, koordinēšanu un kontroli, kā arī personu piedalīšanos kriminālajā izlūkošanā un izlūkošanas informācijas izmantošanu. Likums precīzi regulē kriminālās izlūkošanas darbību - jēdzienus, veidus un instrumentus, informācijas vākšanas metodes, tās izmantošanu, aizsardzību un atbildību par nesankcionētu lietošanu; likumā arī nodalīta tiesībsargājošo iestāžu darbība noziedzịgu nodarỉjumu izmeklēšanā, t. i., kriminālā izlūkošana no izlūkošanas un pretizlūkošanas [2, 3].

Jaunajā dokumentā ir nostiprināta cilvēka tiesību un brīvības aizsardzība kriminālās izlūkošanas veikšanā. Tiek uzsvērts, ka atsevišşu tiesību un brīvības ierobežošanai ir îslaicīgs raksturs un to var izmantot tikai atbilstīgi likumdošanai un tikai cita cilvēka tiesību un brīvības, īpašuma, kā arī sabiedriskās un valsts drošības aizsardzības labā. Pamatojoties uz jauno likumu, kriminālās izlūkošanas izmeklēšana tiks veikta tikai gadijumos, kad ir informācija par gatavošanos izdarìt noziegumu vai par jau izdarītu noziegumu; aizdomās turamais, apsūdzētais vai notiesātais slēpjas; cilvēks ir pazudis bez vēsts; tiek ìstenota personu aizsardzība no noziedzīgas ietekmes. Turklāt likums paredz, ka kriminālo izlūkošanu nevar veikt pret Valsts prezidentu [3].

Atbilstīgi likumam, ja kriminālās izlūkošanas subjekts ir konstatējis, ka kriminālās izlūkošanas gaitā iegūtā informācija par tās objektu neapstiprinājās, informācijas vākšana par objektu nekavējoties jāpārtrauc, bet savāktā informācija jāiznīcina. Ja pēc kriminālās izlūkošanas izmeklēšanas pabeigšanas tās gaitā savāktā informācija par objektu netiks izmantota, tad savāktā informācija par objekta privāto dzīvi jāiznīcina trīs mēnešu laikā. Ja pret personu tika izmantota kriminālā izlūkošana un tās gaitā ievāktā informācija neapstiprinājās, pirmstiesas izmeklēšana netika uzsākta, bet radās negatĩvas juridiskas sekas personām, tad pēc šo personu lūguma jāuzrāda kriminālās izlūkošanas gaitā par tām savāktie dati. Ja persona uzskata, ka kriminālās izlūkošanas subjektu darbību dēl ir pārkāptas tās tiesības un brīvība, tai ir tiesības tādas darbības pārsūdzēt galvenās kriminālās izlūkošanas iestādes vadītājam vai viṇa vietniekam un prokuroram, bet gadījumā, ja nepiekrīt viṇu lēmumam, - vērsties ar prasību tiesā [4].

Minētā tiesību akta skaidrojumā uzsvērts, ka jaunais likums nodrošinās arī daudz augstāku cilvēka tiesību un brīiības aizsardzības līmeni, būtiski palielinās prokuratūras un tiesu kontroli kriminālās izlūkošanas subjektu darbības jomā, l̦aus tās subjektam nodrošināt apstākḷus efektīvākai cīṇai ar noziedzību. Pēc dažu augstākstāvošu valdības locekḷu un parlamentāriešu domām, minētajam likumam piemìt noteikti "drošinātāii", kuri sekmē un ḷauj tiesībsargājošajām institūcijām vajadzīgā veidā nodrošināt cilvēka tiesību un brīvības aizsardzỉbu pret nelikumīgu vajāšanu, izsekošanu vai citu darbību. 
Tādējādi Operatīvās darbības kontroles parlamentārā komisija varēs iegūt vairāk informācijas, kuru nevarētu saṇemt Operatīvās darbības likuma darbības laikā, kā arī efektīvi veikt parlamentāro kontroli [4]. Pēc bijušā Lietuvas Seima spīkera domām, Lietuvas Republikas Kriminālās izlūkošanas likums ir sagatavots kvalitatīvi un profesionāli, n,emot vērā citu valstu pieredzi līdzīgos projektos. Turklāt Seima bijusī spīkere Irēna Degutiene (Irēna Degutienè) akcentē, ka šì likuma pieņemšana ir konstruktīva un mērḳtiecīga darba rezultāts, realizējot kontroles nostiprināšanas un izlūkošanas koordinēšanas koncepciju, ko apstiprinājusi Valsts drošības padome, kā arī atzīst, ka bija nepieciešams saskaņot Operatīvo darbību likuma normas un nodalīt izlūkošanas jēdzienu no kriminālās izlūkošanas jēdziena [7]. Tādējādi tika sagatavoti divi Lietuvas Republikas likumi: Lietuvas Republikas Izlūkošanas likums un Lietuvas Republikas Kriminālās izlūkošanas likums.

Un tomēr Lietuvas Republikas Kriminālās izlūkošanas likumam bija jāaizvieto Operatīvās darbības likums. Šĩ jaunā dokumenta autori apgalvo, ka operatīvās darbības tiesiskā reglamentēšana nebija pietiekama un negarantēja vajadzīgo cilvēka tiesību un brīvības aizsardzību [6]. Minētā likuma pretinieki šaubās par likuma istenošanas caurspīdīgumu - kriminālās izlūkošanas gaitā persona var tikt pakḷauta tiesiski nesankcionētai izsekošanai. Saskatot vispārējas izsekošanas draudus, daži parlamenta locekḷi likuma pieṇemšanas stadijā bija gatavi vērsties pie prezidenta, lai minētajam likumam noteiktu veto [5].

Kā apgalvoja Valerijs Simuliks (Valerijus Simulikas), viens no Seima Cilvēktiesību komitejas locekḷiem, kurš bija pret šì likuma pien̦emšanu, tas paver ceḷu neierobežotai un nekontrolētai personu izsekošanai. Politiḳis uzsver faktu, ka tagad amatpersonas varēs veikt aizdomās turētās personas fizisku izsekošanu trīs dienas bez tiesas lēmuma, ņemot vērā tikai operatīvo informāciju, un aț̣auju tam izsniegs nevis tiesa, bet gan tiesībsargājošā resora darbinieka vadītājs, kurš veic izsekošanas darbību, vai viṇa pilnvarots vietnieks, kas izraisīs spekulatīvas darbības [4].

Tiesību un kārtības parlamentārās komitejas vadītājs Stasis Šedbars (Stasys Šedbaras) atzina, ka dokuments, iespējams, nav absolūti pilnīgs, bet noraidīja apgalvojumus par iespējamu globālu un nekontrolētu personu izsekošanu, kā arī iespējamu launprātīgu izmantošanu no amatpersonu, kriminālās izlūkošanas subjektu puses un, aizstāvot likuma statūtus, uzsvēra, ka līdz šim pastāvošais Lietuvas Republikas Operatīvās darbības likums vispār nedefinēja fizisko izsekošanu, tāpēc darbības nebija juridiski reglamentētas, bet minētais nolikums tiecas to sakārtot. Likuma autori arī uzsvēra, ka telefonsarunu noklausī̌̌anās un ziņojumu kontrole citos elektroniskajos līdzekḷ̆os, tāpat kā līdz šim, būs iespējama tikai ar tiesas sankciju. Pēc likuma sankcijas uz sarunu slepenu noklausǐšanos izsniegs tikai apgabaltiesu priekšsēdētāji vai viṇu pilnvaroti tiesneši, pamatojoties uz prokuroru motivētiem priekšstatiem [6].

Turklāt steidzamos gadījumos, kad rodas draudi cilvēka dzīvībai, veselībai, īpašumam, sabiedrības vai valsts drošỉbai, kriminālās izlūkošanas darbības aț̣auts veikt, pamatojoties uz prokurora lēmumu [6]. 
Atbilstīgi likumam kriminālās izlūkošanas informācijas vākšanas veidi ir šãdi:

- aǵentūras darbība;

- aptauja;

- apskate;

- kontrolpārbaude;

- kontrolējama transportēšana;

- noziedzīga nodarījuma imitācija;

- slēpnis;

- izsekošana;

- slepena operācija;

- tiesībsargājošo institūciju uzdevums.

Likumā ir noteikts, ka galvenās kriminālās izlūkošanas institūcijas, kuras realizē kriminālās izlūkošanas informācijas vākšanu un šīs darbības metodes, ir šādas [1]:

1. Lietuvas Republikas Iekšlietu ministrijas Finansiālo noziegumu izmeklēšanas dienests;

2. Lietuvas Republikas Iekšlietu ministrijas Policijas departaments;

3. Lietuvas Republikas Iekšlietu ministrijas Vadības apsardzes departaments;

4. Lietuvas Republikas Iekšlietu ministrijas Valsts robežapsardzes dienests;

5. Lietuvas Republikas Iekšlietu ministrijas Muitas departaments;

6. Speciālās izmeklēšanas dienests.

Kriminālās izlūkošanas galveno institūciju tiesības un pienākumi delegéti arī Lietuvas Republikas Aizsardzības ministrijas Operatīvo dienestu 2. departamentam un Valsts drošības departamentam, kad to apakšvienības veic kriminālās izlūkošanas izmeklēšanu.

Vienlaikus ar spēkā esošā Lietuvas Republikas kriminālās izlūkošanas likuma izmaināan no 2014. gada 1. janvāra par pilnvērtīgu kriminālās izlūkošanas institūciju atkal kluva Lietuvas Republikas Tieslietu ministrijas Ieslodzijuma vietu departaments, pēc 14 gadu pārtraukuma saṇemot visas tiesības kā pamatinstitūcija, kas realizē kriminālās izlūkošanas darbību valsts labošanas sistēmā.

\section{Secinājumi}

Lietuvā sabiedrības drošības tiesiskās regulēšanas jomai ir tendence mainīties un attīstìties. Šajā posmā svarīgs faktors ir Lietuvas Republikas Kriminālās izlūkošanas likuma stāšanās spēkā. Varas pārstāvji atš̌kirīgi vērtē šĩ likuma pien̦emšanu un tā ietekmi uz sabiedrības drošību. Pēc zinātniskās sabiedrības, īpaši juridisko zinātņu pārstāvju domām, Lietuvas Republikas Kriminālās izlūkošanas likuma pien̦emšanā iezīmējas šì tiesību instrumenta svarīgums un savlaicīgums:

- tas ir savlaicīgi izstrādāts un iedzīvināts tiesiskās regulēšanas avots, kas virzìts uz demokrātisko vērtību aizsardzību, kā arī cilvēka tiesību un brīvības ievērošanu; 
- tas garantē mērḳtiecīgus, secīgus un objektīvus tiesībsargājošo institūciju darbības mērus un metodes, kas apveltītas ar leǵitīmām pilnvarām valsts drošîbas nacionālās politikas realizācijā;

- tas sekmē valsts iestāžu darbinieku slepenas darbības uzlabošanu un pilnveidošanu, kas virzīta uz noziedzīgu nodarījumu novēršanu un personu notveršanu, nozagta īpašuma meklēšanu un citām darbïbām, kas saistītas ar valsts un vērtību nacionālo drošīibu.

\section{Security Issues: Current Trends in Lithuanian Law Enforcement System}

\section{Abstract}

Problems in the sphere of national security of Lithuania draw attention to the fact that the management and use of information as a traditional working method of law enforcement institutions is changeable because of the increased involvement of security services and their attention towards current threats to security. Observation over the running and fast changing integration processes in the European Union in the sphere of law reforms, provision of security and significant social processes, as well as their study acquire not just a theoretical but also a more practical importance. It requires a close attention within a scientific community, namely, the representatives of legal sciences.

The work presents the current issues and latest trends of development in the sphere of law regulation of the public security stipulated by the adoption of the Law of Criminal Intelligence of the Republic of Lithuania, which have not received yet a comprehensive and detailed reflection in scientific debates. Therefore, it is necessary to analyse the implementation of this legal instrument in the sphere of secret activity of Lithuania's security at the present stage within the globalisation process. The author applied general scientific methods of studying objective reality and means and techniques peculiar to legal sciences. As a result, the significance and urgency of this legal instrument as a guarantee for protection of democratic values and human rights and freedoms have been emphasised.

Keywords: security of society, criminal intelligence, human rights and freedoms.

\section{Literatūra}

1. Lietuvos Respublikos kriminalinès žvalgybos įstatymas. 2012 m. spalio 2 d. Nr. XI-2234, Vilnius. Iegūts no: http://www3.Irs.lt/pls/inter3/dokpaieska.showdoc_l?p_id=437554

2. Lietuvos Respublikos žvalgybos įstatymas. $2000 \mathrm{~m}$. liepos 17 d. Nr. VIII-1861. Vilnius. Iegūts no: http://www.infolex.lt/ta/161012:ver1:str1 
Vladas Tumalavičius. Drošības jautājumi: mūsdienu tendences Lietuvas tiesību aizsardzības sistēmā

3. Принятый Закон о криминальной развеАке позволяет 3 Аня вести слежку без санкции суда. Delfi.lt. Iegūts no: http://ru.delfi.lt/archive/article.php?id=59635701

4. Seimas prièmė Kriminalinès žvalgybos ịstatymą. Delfi.lt. Iegūts no: http://www.delfi.lt/news/ daily/lithuania/seimas-prieme-kriminalines-zvalgybos istatyma.d?id=59633507\#ixzz2ZaL oMHQ6

5. Sukritikuotas Kriminalinės žvalgybos įstatymas. Infolex.lt. Iegūts no: http://www.infolex.lt/ portal/start.asp?act=news\&Tema=1\&str $=51303$

6. Seimas prièmė Kriminalinès žvalgybos įstatymą. Lrytas.lt. Iegūts no: http://www.lrytas.lt/ lietuvos-diena/aktualijos/seimas-prieme-kriminalines-zvalgybos-istatyma.htm?p=2

7. Lietuvos politika. I. Degutienė: Kriminalinės žvalgybos įstatymas visuotinio sekimo neịteisins. Respublika.lt. Iegūts no: http://www.respublika.lt/lt/naujienos/lietuva/lietuvos_politika/ idegutiene_kriminalines_zvalgybos_istatymas_visuotinio_sekimo_neiteisins/,print.1

8. Ронин, Р. Своя разведка: способы вербовки агентуры, методы проникновения в психику, форсирование воздействия на личность, технические средства скрытого наблюдения и съема инбормации. Практическое пособие. Мн: Харвест, 1998. 368 с. ISBN 985-433-180-6.

9. Сысалов, М. П. Основы оперативно-розыскной деятельности. Учебник. Алматы: Юридическая митература, 2006. 338 с. ISBN 9965-620-33-4. 